\title{
Filling in the blanks: Catholic hopes for the English succession
}

\author{
Victor Houliston \\ University of the Witwatersrand \\ Johannesburg, South Africa
}

\begin{abstract}
English Catholics, both at home and abroad, were faced with difficult choices as the question of the succession became increasingly acute in the last decade of Elizabeth's reign. In an attempt to analyse the complexity of Catholic expectations and manoeuvres, this article examines the actions and writings of three prominent figures: the courtier-poet and recent convert Henry Constable, the Jesuit leader Robert Persons, and the layman Sir Thomas Tresham. Their relations with King James VI of Scotland illustrate the precariousness of his position, and their interactions during this period of shifting allegiances call into question some received assumptions about the divisions within the English Catholic community. Close attention to their writing also reveals the significance of an appeal to a chivalric code of honour in these politico-religious negotiations.

KEYWORDS: English succession; recusancy; Jesuits; chivalry; Henry Constable; Robert Persons; Sir Thomas Tresham; James VI and I; Philippe du Plessis-Mornay.
\end{abstract}

One of the most memorable Catholic interventions in the late Elizabethan succession crisis, and one which we may regard as symbolic, was the affair of the Spanish blanks. This was a plan concocted by three Scottish earls, Angus, Huntly and Errol, in concert with the Scottish Jesuits, to invoke the aid of Philip II. The Spaniards would invade from Kirkcudbright, subdue Scotland and

E. ederi 25 (2015: 77-104)

https://doi.org/10.34136/sederi.2015.4 
then England, and restore both realms to the ancient faith. To assure the Spanish king of their support the earls supposedly signed blank papers which were found on their emissary, George Kerr, when he was apprehended at Fairlie Road on 27 December 1592 (Stafford 1940:74-123; Law 1904:244-72). Expectations of Spanish-Scottish collaboration in the Catholic cause of Britain were to rise and fade periodically during the late sixteenth century, but what concerns us here is the notion of blank papers signed in hope. In this essay I'd like to develop this notion by suggesting that the blank space of the succession was one where English Catholics, at home and abroad, clerical and lay, could inscribe their hopes for change. ${ }^{1}$ In it, they could write and re-write their future, as each plan or scheme or intervention followed each other.

Catholic activity concerning the succession was erratic because the scene was continually shifting. In the court, there was the EssexCecil rivalry: Essex seemed more ideologically committed to Protestantism but more generous in spirit, indisposed to persecution and ready to admire the constancy of suffering priests (Hammer 1999:174-78). Cecil seemed more pragmatic and might be a likely bet for those who resented the Jesuits and were ready to compromise for a modicum of toleration, but since Essex was posing as James's champion there were moments when it looked as though Cecil might countenance the Jesuits and entertain the thought of a Spanish succession (Hicks 1955; Collinson 2014:111, n. 62). Amongst the Catholic powers in Europe, to whom the Catholics looked for aid in their plight, there was no common policy on the succession. The Spanish royal house had its own claim to the English crown, and so was regarded with suspicion by France. France had an old alliance with Scotland but was afraid that a Scottish succession might lead to a compact with the Netherlands and so revive the ancient threat of Burgundian encroachment (Lee 1970:3-16). The Spanish Netherlands jealously guarded its independence from the Spanish Council of State. The Pope, Clement VIII, felt it incumbent upon him to contain Spanish pretensions. ${ }^{2}$ Spain put on a show of waging holy war

\footnotetext{
${ }^{1}$ The phrase "blank space" is used by Michael Questier (2005:85) to refer to the way Catholics read Elizabeth herself, "inflected and glossed by reference to certain key political topics, principally the succession."

${ }^{2}$ For an intriguing analysis of Clement VIII's attempts to outmanoeuvre Spain, see Cardinal D'Ossat to Henri IV, Rome, 26 Nov 1601, English translation by T. Birch, transcription in Cooper (1886:1.131-45).
} 
against the heretics in England but was only willing to intervene when it suited the most Catholic king.

Events also played havoc with expectations. In 1598 Burghley died, a more dependable figure perhaps than Robert Cecil; so too did King Philip II of Spain, to be succeeded by his irresolute son Philip III. Peace was signed between Spain and France at Vervins in the same year, raising hopes of peace with England and possible concessions to the Catholics. The Spanish Infanta Clara Eugenia, much touted as a possible Catholic candidate for the English throne, married the Archduke Albert in 1599 and thus became joint ruler of the Spanish Netherlands, a position she was very unwilling to risk in favour of an alien crown. Early in 1601, Essex fell, while in September the Tyrone rebellion came to an unhappy end at Kinsale, just when the Spaniards had at last come to the aid of the Irish.

Amongst themselves, the English Catholics, and especially the exiles, were notoriously divided. Sometimes it seemed as though their energies were concentrated more on attacking each other than in trying to improve their condition within the state. The clergy imprisoned at Wisbech Castle were divided between the strict followers of the Jesuit William Weston and the more easy-going seculars. Some students at the English College in Rome saluted Spaniards obsequiously in the streets while others thumbed their noses and muttered curses about Jesuits and bad fish. Many students deliberately joined the Benedictines, in protest against the Jesuits. In Flanders a party of exiles kept trying to influence the nuncio against the Jesuit William Holt. When an archpriest was appointed in 1598 to rule over the secular clergy in England, an aggrieved party, sensing a Jesuit bid for total control of the Catholic community, sent delegates to Rome and mounted increasingly scurrilous printed attacks on their favourite enemy, Robert Persons, leader of the Jesuits, rector of the English College in Rome and confidante of the Cardinal Nephew Aldobrandino. The Bishop of London, Richard Bancroft, eagerly accepted the appellants' offers of collaboration against the Jesuits, helped to print their slanderous books, and chuckled at the prospect of Catholic self-destruction and the naïveté of the seculars' hopes for toleration (Jenkins 1948; Collinson 2014). Amongst the laity, there was no agreement on the vexed questions of church attendance and allegiance to the excommunicated queen. 
The reasons for this fragmentation are complex, but not hard to understand in a context of long frustration and persecution. Conflict surfaced after the defeat of the Spanish Armada, which had proved that Catholics would not rise as a united body against the Protestant regime. The death of William Cardinal Allen in 1594 signalled the loss of a powerful unifying figure. In the same year, the conversion of the French king Henri IV initiated a period of gradual religious reconciliation in France, which tended to weaken the resistance of English Catholics. The Jesuits, who had won the admiration of the Catholic community in the heroic days of the English Mission, now began to look like extremists who had sold out to the Spanish monarchy. Robert Persons was suspected of manipulating Roman policy towards England by controlling the flow of intelligence and charming the papal court.

This rather bewildering and volatile scene was naturally characterized by a series of moves and counter-moves, some of which have been expertly analysed in a recent book of essays on the succession (Doran and Kewes 2014). It is nevertheless possible to detect, behind the manoeuvring, some significant patterns of Catholic thinking about the matter. It was in fact not so much who they wanted as what they wanted that counted. And what we shall see is that a large number of Catholics kept working right up to the moment of James's accession and beyond, to try to secure the best possible terms. In this essay I shall consider the interventions of three diverse figures from the years 1600 to 1604 - Henry Constable, Robert Persons and Thomas Tresham - to illustrate different strands of Catholic response, and will try to show both the overlaps and the disparities among them. In so doing, I shall also argue that James's succession was by no means so assured that this was not an extremely nervous transition.

\section{II}

One of the most intriguing participants in the Catholic manoeuvrings over the succession was the courtier and poet Henry Constable (Wickes 1953-1954). His father, Sir Robert Constable (d. 1591), had been master of the Queen's ordinance and an associate of the exiled Earl of Westmorland, Charles Neville, a somewhat dissipated survivor of the Northern Rebellion of 1569. Westmorland 
was a potential rival to Sir William Stanley as a military leader of the English Catholic exiles (Loomie 1963a:133), and in 1600 Henry Constable planned to involve him in an ambitious scheme for the conversion of England by means of France. ${ }^{3}$ This placed Constable in the anti-Jesuit camp, but he had previously been in friendly correspondence with Persons and so is an interesting case study of the overlap between the two major parties. He began with high hopes for the conversion of James VI, whom he visited in 1599, in response, it seems, to the approach James made (or was claimed to have made) to the Pope Clement VIII earlier in the same year. ${ }^{4}$ At some point during this visit Constable appears to have been drawn in to a papal offer to pay large sums of money to James if he would convert. This came to nothing and he returned to Paris disappointed. Clearly James was going to need more inducement than religious persuasions or cash benefits. Constable thus wrote to the Pope and to Cardinal Baronio to propose bringing France into the game. In Rome, Persons was consulted and dismissed the idea. He had very little confidence in any scheme involving James. So Constable turned to Persons's enemies amongst the exiles in Flanders and Paris, including William Gifford, Dean of Lille, the most eminent of the English anti-Jesuits on the continent and later to become revered in the English Benedictine revival (McCann 1952:137-60). Together they worked out a plan for an Anglo-French treaty allowing for limited liberty of conscience during the rest of Elizabeth's reign, with a promise for more under James. Constable then departed for Rome to drum up support.

Despite Constable's wide network and diplomatic skills the plan collapsed, partly because of the fall of Essex, whom he had hoped to enlist, along with other members of the Privy Council. But the initiative is significant because it brought to the surface several related strands of English Catholic culture - loosely associated with the settlement of the wars of religion in France following the conversion of Henri of Navarre - which we might in some sense

\footnotetext{
${ }^{3}$ Details of Constable's plan are from Persons's report to the Duke of Sessa, early 1601 (CSP Simancas 4:681-2), and so should be treated with due caution.

${ }^{4}$ W. Crichton to Thomas Owen, 4 June 1605 (Archives of the British Province of the Society of Jesus, hereafter ABSI, MS Anglia III, 55 and 46/4/10, fols 161-62). Grateful thanks to Rebecca Volk, archivist of the British Province of the Society of Jesus, for permission to consult and quote from these sources.
} 
regard as ecumenical. For one thing, before allying with Gifford and Charles Paget, who were definitely Persons's adversaries, Constable also approached Persons's colleague Dr Barrett, Rector of the English College at Douay, and Thomas Stapleton, Professor at Louvain and the most distinguished contemporary English Catholic theologian. So he was trying to be as inclusive as possible in his enterprise. For another, his hopes of winning Essex as an ally crystallised the gathering expectations of the role he might play in gaining toleration for the Catholics. In addition, his view of the restoration of the faith in England was shaped largely by the nature of his own conversion and the spectacle of Catholicism gradually gaining the upper hand over the Huguenots in France. Finally, he wrote and published an English book, A discoverye of a counterfecte conference (1600), attacking Persons for the notorious Conference about the Next Succession (1595) and setting forth a compelling alternative vision of the relation between church and state.

The Essex factor complicated a lot of calculations in late Elizabethan England, partly because he was impulsive and cultivated a chivalric air of frankness and generosity. Trying to impress Elizabeth with his spy network he engineered the cruel death of Dr Lopez in 1594, which led to a brief intensification of antipapist activity in London and indirectly to the imprisonment of the Jesuit John Gerard. Later Essex expressed his admiration for Gerard's constancy in the Tower, where he was hung up by his hands, and references in Henry Garnet's letters to Persons suggest that the earl was an object of intense interest and fascination for the Catholics. ${ }^{5}$ There is an undated petition appealing to him to use his influence with the queen in favour of toleration, probably from 1598 (Loomie 1963-1964); there were several Catholics in his entourage and even Persons was reported to be sending out probes in his direction. ${ }^{6}$ When he was appointed to lead the English forces against Tyrone in Ireland, the Brussels nuncio Frangipani planned to send Richard Stanihurst to treat with him (Lennon 1980:52-53). There was hope, then, that Essex might play a part in bringing about a new dispensation in Ireland, which could be a precursor to a settlement in England itself. Since he was also putting a lot of effort into

\footnotetext{
${ }^{5}$ Extracts from Letters of Henry Garnet, chiefly to Robert Persons (ABSI, Collectanea P 536-54, esp. 547-48, 550).

${ }^{6}$ E.g. Anonymous intelligence, June 1599 (CSPD 1598-1601:227-29).
} 
establishing himself as James's champion in the succession stakes, he was clearly someone for Catholics to monitor closely. He was closely associated, as the inheritor of the Sidney mantle, with the "forward" party in English Protestantism, but he may have felt ashamed of his part in the victimization of Lopez, was constitutionally averse to religious persecution and liked to think of himself as always fair to his opponents.

Against this background, Essex seemed to represent openness to an ecumenical spirit, in which debate and interchange could take place in a less adversarial manner. Constable corresponded regularly with him from 1595 to 1597.7 It was Essex who intervened on behalf of the former Jesuit priest Thomas Wright, who spent some years in various prisons in the late 1590 s and was instrumental in the celebrated conversion of William Alabaster, one of the brightest hopes of the late Elizabethan English church. Together they held prison disputations with leading Protestant bishops, to the great satisfaction of Catholic observers. ${ }^{8}$ As it happened, there occurred in May 1600, just when Constable was on the point of leaving Paris for Rome in pursuit of his grand scheme for the conversion of England, a public disputation at the royal palace of Fontainebleau only a few miles away. The whole city was buzzing in anticipation, for the event had been prompted by the accusation that the Huguenot lay champion, Philippe du Plessis-Mornay, had been guilty of over five hundred falsifications in his refutation of the mass. He had therefore challenged the Catholic bishop Davy du Perron to make good the charges (Daussy 2002). ${ }^{9}$ Perron was himself a former Huguenot, and had instructed the convert Henri of Navarre in the Catholic faith. It

\footnotetext{
${ }^{7}$ E.g. Constable to Essex, 28 Feb/10 Mar 1597 (HMC Hatfield House 7:86).

${ }^{8}$ On Alabaster and Wright, see Richard Percival to Sir Robert Cecil, Strand, 22 Sept. 1597 (HMC Hatfield House 7:394), Examination of Wm. Alabaster before Sir John Peyton and Attorney General Coke, Tower of London, 22 July 1600 and Analytical abstract of the evidence in support of the charge of treason against the Earl of Essex (CSPD 1598-1601:453-55), Letters of Henry Garnet (ABSI Collectanea P, 549, 551-52), "The Conversion of Alabaster" (Bodleian Library MS Eng. Th. b1, Jollet Miscellany, lib. 19, fol. 235), Stroud (1951), and Sutton (1997).

${ }^{9}$ Contemporary accounts of the trial include Discours véritable de la conférence (1600), commonly attributed to Mornay and anonymously translated as $A$ Discourse of the Conference (1600). The work that sparked off the controversy was Mornay's De l'Institution, usage, et doctrine du Sainct Sacrement de l'Eucharistie (1598), translated as Fowre Bookes, of the Institution, Use and Doctrine of the Holy Sacrament of the (1600).
} 
would have been strange if Constable had not been deeply interested in the disputation, for he had some years previously written a book, the so-called Catholic Moderator (1589) in which he posed as a Catholic responding in an ecumenical way to Huguenot objections to the faith (Rogers 1959-1960). This book was often attributed to Perron, and Constable was so successful in putting forward a Catholic point of view that he converted himself.

John Bossy has memorably characterized the procedure of The Catholic Moderator, judging that "Constable's method of stopping controversy was to produce formulae so vague as to evacuate the intellectual content of the views of both sides" (Bossy 1961-1962:23031). This may be a rather harsh judgement. Constable identified and then categorized each point of difference in such a way as to demonstrate that there was no burning issue. On justification by faith, for example, he averred (1623:8): "only we differ in termes: the Huguenots calling Faith without Charitie, an Historicall or dead Faith; and we, a Faith without Forme. O my God, what a pittie it is, to behold the simplicitie of our Christian Faith, thus puzzled about these quiddities."10 He was not, of course, a trained theologian, but he represented the common-sense view, no doubt shared by many, that Protestants and Catholics could resolve their differences by smoothing over the spiky points of doctrine and ecclesiastical discipline. James VI occasionally thought along these lines, and hoped to contribute to the reunification of Christendom by persuading his fellow princes to call an ecumenical council at which the Pope would be invited to preside without exercising papal control. ${ }^{11}$ So it is not surprising that Constable continued, despite his failure to convert James, to support his candidature for the succession and to oppose the campaign for the Infanta. This is the context for his attack on Persons's Conference in $A$ discoverye of a counterfecte conference, which was published in Paris in 1600 at the expense of Charles Paget, a close associate of William Gifford and collaborator in the Constable succession initiative.

\footnotetext{
10 The French reads: "Seulement nous parlons en diuers termes, les Huguenots appelans la foy sans charité, foy historique, ou morte, \& nous foy sans forme. Mon Dieu, quelle pitié de voir la simplicité de la foy Chrestienne, embrouilleé des ces subtilités" (Constable 1589:17).

${ }^{11}$ For James's negotiations with Pope Clement VIII, 1601-1604, see Patterson (1997:39$41)$.
} 
As behoves the work of a man of letters, the Discoverye of a counterfecte conference is constructed according to the conventions of classical rhetoric, as an epideictic oration in dispraise of Robert Persons. ${ }^{12}$ The exordium dilates on the theme of "estimation" and the peroration contrasts Persons's manner of proceeding in the matter of the succession with that of the Pope, concluding with the proper aspiration that the Jesuit should look to the health of his soul. The argument is that Persons's Conference is to be deplored for its matter, its structure and its consequences, and the burden of the work is to elaborate the destabilizing effects of making religion the determining factor in the government of the realm. Persons is guilty of "monstrous excesse in speeche" (Constable 1600:41), of promoting a "sodainly supposed pretender" (8), a political philosophy "(n)euer herde or thought of in the memorye of man" (12-13), his language full of "surmise of doubtfulness" (31), "lothesome drifts and scoopes" (11) and "disorderly [...] light [...] phantastical [...] fable(s)" (5). Constable wants a settled monarchical rule with papal endorsement, based on ancient laws and customs, reason and established procedure. The commonwealth should be established on a common ground of virtue and piety, and religious controversy can work itself out in peace.

\section{III}

The stridency of Constable's tone towards Persons may be a function of printed polemic rather than personal disaffection, but it aligns him with the abusive rhetoric of the appellants whose voluminous assaults on Persons were pouring off the London presses throughout 1601 and $1602 .{ }^{13}$ It seemed to them that the only way of negotiating a form of toleration for the Catholic Church in England was to remove the Jesuit threat altogether. Whether James remained Protestant or slid towards Catholicism in view of the overwhelming weight of evidence in favour of the faith of the Fathers (for the Huguenot had been utterly trounced at Fontainebleau), the nation was much more

\footnotetext{
${ }_{12}$ Classical rhetoric is divided into three branches: forensic (proving guilt or innocence), deliberative (advocating one line of policy or another) and epideictic or demonstrative (elaborating praise or dispraise).

${ }^{13}$ The attack on Persons can be found in most concentrated form in William Watson's Decacordon (1602).
} 
likely to prosper with an old-fashioned easy-going Catholic hierarchy than with a fanatical Jesuit cohort driving men and women to fervour and sacrifice and even martyrdom if they didn't get their way. ${ }^{14}$

From Persons's own point of view, the dissidents in Flanders and Paris, at Wisbech and the English College in Rome, and especially the appellants, constituted the threat. They were factions, breaking up the unity of the English Catholic church. Certainly the Jesuit himself had a gift of impressing those he met with his wider vision of the faith restored. In 1600 he was a force to be reckoned with, and he too took a lively interest in the proceedings at Fontainebleau. He exploited Perron's triumph in a Relation of the Triall, originally published in 1601 (although no copy is extant) and revised and extended in 1604 as an appendix to his Treatise of Three Conversions of England. ${ }^{15}$ This is a significant little work because it reflects Persons's expectations of the procedure to be followed for dealing with heresy after the restoration of Catholicism in England under the next Catholic prince, a consummation for which he was arduously scheming and which did not include James VI. His view of reunion through state-controlled public disputation, the gradual extinction of opposition under a Catholic monarchy, was coloured differently from that of Constable or Gifford, or for that matter Alabaster, who lost his enthusiasm for the Catholic faith when he entered the more triumphalist atmosphere of Rome in the early 160os. But by 1604, when Persons re-published the work with a hastily rewritten preface, James was established as king, so the account of the disputation had a rather different thrust: to guarantee the standards for religious controversy so that, even under a Protestant regime, the truth would be sure to triumph. And here he promoted an ethos that brought him closer to Constable's vision: the code of chivalry, introducing an element of honour into the polemical scene. This was prompted by the fact that the Huguenot, Philippe du PlessisMornay, was by the calling of his birth a feudal lord, defending his

\footnotetext{
${ }^{14}$ I owe this explanation of the viewpoint of the seculars/appellants to discussions with Michael Questier.

${ }^{15}$ Persons's account, A Relation of the triall made before the King of France, upon the year 1600, betweene the Bishop of Evreux, and the L. Plessis Mornay, was appended to the second volume of $A$ Treatise of Three Conversions of England from Paganisme to Christian Religion (1603-1604).
} 
honour before the king, rather than a theologian defending a thesis in an academic hall (Houliston 2008).

One of the most difficult, and no doubt painful, letters Persons had to write in his life was his letter of 18 October 1603, congratulating James on his accession (McCoog 2004:210-15). But even before then he felt it expedient to write to James VI to explain his position. This was a letter dated at Rome, 18 August 1602 (McCoog 2004:208-10). It was written at an important turning point in the Jesuit's strategy with regard to the succession, when Pope Clement VIII sent Sir David Lindsay as an emissary to James VI outlining the conditions under which the papacy would be prepared to endorse his candidature. Persons's letter went with him: a reversal from 1599, when Constable had approached James against Persons's wishes and rather dubiously represented the Pope. To understand the significance of this shift we need to outline briefly how Persons had approached the succession issue since the failure of the Spanish Armada of 1588 .

It needs to be reiterated that at no time did Persons place any hopes or confidence in James VI, even though he was the son of Mary Queen of Scots whose execution had intensified the fervour of the Armada. Persons's involvement in earlier invasion plans had taken it for granted that Mary would lose her life in the process - i.e. she was expendable - and this was one of the deep sources of the conflict with the opposition party among the exiles in Flanders and Paris (Martin 1973; Guilday 1914:93-95). They were emotionally tied to Mary and resented the predominance of the Spanish interest in Persons's schemes. But Persons was not so much pro-Spanish as anti-James, and in this he could claim to have judged rightly. The Catholics soon found, after his accession, that James was not to be trusted. ${ }^{16}$ Thus in all his activity regarding the succession Persons consistently sought to weaken James's position, or, at the very least to make him insecure enough to seek an alliance with the Catholics and commit himself to conversion or toleration. The first potential alternative candidate he probed was Ferdinando Stanley, Earl Strange and heir of the Earl of Derby. Although the evidence is

\footnotetext{
${ }^{16}$ From McCoog's account (2004:189-90), of Persons's letter to Henry Garnet, 24 May 1603 , the impression might be gained that Persons shared the temporary optimism following James's accession, but in July he wrote to "Antony Rivers" showing neither surprise nor disappointment that "men begin to droope agayne" (Pollen 1906:214-15).
} 
scanty and ambiguous, it seems clear that he sent agents to sound him out in 1591 and he was probably behind an attempt by Richard Hesketh to approach the newly elevated Fifth Earl of Derby in 1593. Stanley immediately turned the luckless Hesketh in to be hanged, but died himself soon afterwards. Predictably, the Jesuits were suspected of foul play. ${ }^{17}$ We cannot know for sure how much Persons was invested in this possibility, but the Derby line was more or less out of the running by the time the Conference about the Next Succession was completed later in 1593.

There is not the space here to go into the question of the authorship and intent of the Conference, which has been the subject of a great deal of controversy. ${ }^{18}$ My own view is that the work was compiled, chiefly by Persons, with the approval of William Allen, as a way of displacing James VI from front-runner status and alerting the Catholic community to the conscientious imperative not to support a Protestant candidate. It stopped short of declaring the Infanta of Spain as the favoured Catholic candidate, but it laid the foundation for a unified Catholic policy on the succession (Houliston 2000). When it was eventually published, in 1595, with a dedication to Essex, Allen was dead and the work became a political football both in the English court and in the tents of the exiles. Essex, who was trying to cultivate James, was embarrassed; ${ }^{19}$ Burghley made sure that a copy was sent to James, ${ }^{20}$ in Flanders Gifford gloated that

\footnotetext{
${ }^{17}$ The fullest account is by Bagley (1985:59-67). Thomas Bell, a renegade priest who assisted Strange's father, the 4th Earl, with a recusant purge in 1592, claimed in his Anatomie of popish tyrannie (1603) that Persons had set on Hesketh to stir the 5 th Earl to rebellion (dedicatory epistle, sigs. II $3 \mathrm{v}-4 \mathrm{r})$. The Scottish Jesuit William Crichton discusses the Jesuit interest in the Derby succession, in a letter to the General, Acquaviva, Brussels, 13 January 1594 (Medina 1996:232, 244-45). For Persons's earlier involvement, see his letter to John Cecil and John Fixer, 13 April 1591, containing coded references, possibly, to Lord Strange (HMC Hatfield House 4:104-105), the confession of Thomas Christopher [alias] Dingley to Lord Burghley, 24 August 1592 (CSPD 1591-1594:255-56), and the statement by John Snowden (i.e. Cecil) to Lord Burghley, 21 May 1591 (CSPD 1591-1594:39-40). Francis Edwards (1995:146-47) suggests that Persons and Strange may have been the victims of Burghley's machinations.

${ }^{18}$ Most scholars now accept the conclusion of Peter Holmes (1980). The evidence is laid out by L. Hicks (1957-1958), who comes to the opposite conclusion, namely that Persons was not the chief collaborator.

${ }^{19}$ Rowland Whyte to Sir Robert Sidney, London, 5-12 November 1595 (HMC L'Isle 2:182-84).

${ }^{20}$ W. Cecil to R. Cecil, London, 3 October 1595 (Peck 1779:1.169-70).
} 
Persons had ruined himself with the Pope ${ }^{21}$ and the Scottish Jesuit William Crichton invoked French folklore to comment that you cannot catch a hare by beating a drum. ${ }^{22}$

There certainly seemed to be something mischievous about the publication of the Conference, which cast thorns in James's path. And it does not seem to have persuaded Catholics generally to be "indifferent" enough about the succession to accept the Infanta as a candidate once the real campaign began. Nor could Persons and his associates count on any sustained support from Philip II, although there was an attempt at a second Armada in 1596 and again in 1597. In 1597 Persons himself moved to Rome from Spain, where he had had some influence with Philip II. Then Philip died and peace was signed with France, the Infanta married the Archduke and transferred to the Netherlands. Despite prompting from Joseph Creswell, now the leading English Jesuit in Spain, and the Duke of Sessa, the Spanish ambassador in Rome, Philip III took an unconscionable time deciding whether he would support his sister's candidature, and when he finally did so, in February 1601, it was clear that the Infanta was averse to the plan. In any case, Clement VIII was advising Persons and Sessa that the French would be opposed to the Infanta (Loomie 1965:503; Hicks 1955:131). Meanwhile the more militant Catholics in England, including some of those who would later be involved in the Gunpowder Plot, were pressing Creswell to find Spanish support for an armed insurrection (Pollen 1903:577-80). They continued to hope right through the first months of James's reign, but in vain. The special Spanish envoy, Juan de Tassis, toured England at the time and was half-expecting something to happen, but the left hand did not know what the right hand was doing (Loomie 1963:15-19; 1973:16). In the summer of 1602, Persons, somewhat reluctantly, was moving on. It was time to put some more pressure on James. So he wrote the letter that the Pope's emissary bore with him along with Clement's offer of conditional endorsement.

James wanted the English crown so much that he was ready to entertain all proposals. But Persons's letter, while preparing the

\footnotetext{
${ }^{21}$ W. Gifford to T. Throckmorton, 15 June 1595 (CSPD 1595-1597:54-55).

22 "Est proverbium Gallicum, leporem non esse capiendum tympano," W. Crichton to R. Persons, 20 August 1596 (ABSI, Collectanea P 318; Knox 1882:384).
} 
ground for reconciliation, firmly insisted that the king's religion was an insurmountable barrier to Catholic support. He began by explaining his explanation:

The occasion of this bearers jorney, Sir James Lynsie, and his most loyall hart towards your Majestie together with his Christian zeale towards God and his Religion, hath emboldened me to write these few lynes to your Majestie wherunto I have byn much encouraged also by the example of some of my ecclesiastical superiours, who therby have delivered me from that feare and scruple of Conscience which hitherto hath not a little hindred and drawne backe both me and others from declaring the doubtfull affections of our mynds by reason of the difference of Religion presumed to be betwene your Majestie and us, and many thousands of my nation, who otherwise do beare a most faythfull hart towards your Majestie and his service, with an ardent desyre of his highest advancement both in this world and the next. (McCoog 2004: 208)

In other words, "I am now emboldened to declare the doubtful affections of my mind." The phrase "declaring the doubtfull affections of our mynds" does not mean that he is now ready to disclose his undivided affection but rather that he is now bold enough to explain why his affections are doubtful. In diplomatic terms, that is straight talking, and more was to follow:

But that not falling out, and our hopes in the said principall poynt decaying more and more daylie, and that especiallie upon the reports, and [a]sseverations of such as came and writt from those poarts where they were thought to have best cause to know and judge of the likelyhood of matters, your Majestie in his wisdome and equity cannot marvaile, if those zealous endeavours of Catholiques for your Majestie became more cold for the tyme, and some other secondarie cogitations entered also perhaps with some, how to assure themselves by other meanes in that only chief poynt about religion, for which they have suffered so much as all the world knoweth and your Majestie cannot but be informed therof, and for which poynt only they are resolved to postpone all humayne and worldly respectes whatsoever. (McCoog 2004: 209)

That is to say: you can hardly be surprised that English Catholics have been forced to look elsewhere for their political salvation. This is hardly an apology, but an attempt to establish a position of strength, from which Persons can offer an incentive:

And yet was all this notwithstanding (as I verily perswade my selfe) without all diminution of internall affection so long as any 
least hope remayned of the principall poynt which hope they did endeavour by all meanes and arguments to feede still and conserve in them selves together with their desyre of your Majesties greatest preferment, which may be the easier believed, if a man consider the infinite utilitie and interest that would grow to your country and us all therby, (to say nothing of all Christiendome) I meane by the greatnes of your Majesties person and state, if the foresaid only impediment were removed, so as when men are found to speake to their owne profitt they may easely be beleeved to meane as they speake, though other arguments of probabilitye were wanting. (McCoog 2004: 209)

He argues, as a man experienced in the courts of Europe, that officious declarations of potential devotion are not to be trusted; James should rely on the fact that, if he converts, it will be in every Catholic's interest to support him. Finally, Persons withdraws with all the dignity of his priesthood intact:

Our Lord Jesus be your Majesties buckler and defence against all enemyes both spirituall and temporall, and make yow longe and prosperouslie to raigne in the Religion of your Majesties most noble ancient Catholique Christian Kings and Queenes of that Iland, and this is our most earne[s]t prayer for your Majestie and yours daylie, whose hands I kisse most humbly, and with all dewe reverence from Rome this 18 of August 1602. Your Majesti[es] most humble orator \& beadsman. (McCoog 2004: 209-10)

We may choose, if we wish, to read the letter as an exercise in sophistry, or a last-ditch attempt at limiting the damage. What needs to be emphasised is that in the declaration of constancy in inconsistency there is no hint of compromise. When James ignored the letter, Persons responded by pursuing rapprochement with the French. In December and January 1602-1603 he was writing to the experienced Jesuit diplomat Antonio Possevino, in Venice, who had the ear of the French ambassador, Philippe de Fresne-Canaye. He was now proposing that the French should ally with the Jesuits in exerting pressure for toleration on the English Privy Council, and that the kings of France and Spain should unite behind "a thyrde parson nether Spanishe nor frenche to the crowne of England $w^{\text {ch }}$ was the prince of parma." A few weeks later Persons wrote to Constable in Paris, urging union on all fronts: the appellants should submit to the subordination and the " 2 kynges frenche \& chatholique [i.e. Spanish] to ioyne in one to the rootinge oute of heresye." These proposals were pooh-poohed by the appellant party 
in Paris, but the king's minister Villeroy was at least willing to toy with the idea. ${ }^{23}$ Meanwhile Persons may have been exploring yet another option: Arabella Stuart, possibly using as his agent the elusive Father Antony Rivers, in fact (as it now transpires) William Sterrell, the secretary to the Earl of Worcester, one of several Catholic sympathisers in the English court. ${ }^{24}$ The Lady Arabella, immediately next in line after her cousin James VI, could be married off to another contender for the succession: the Prince of Parma or one of the Seymours in the Hertford line, thus strengthening her claim. ${ }^{25}$ Inevitably there were rumours of Jesuit interference with Arbella Stuart, ${ }^{26}$ and in early March she made a frantic attempt to escape from her keeper, the Countess of Shrewsbury at Hardwick Hall, with the help of a local Catholic gentleman related to Thomas Stapleton (Lovell 2005:437-45). One of her proposed husbands, Edward Seymour, Lord Beauchamp, was said to have 10 ooo men in arms with the French and the Spanish lurking in the background, and he had to hasten to explain himself once James was securely in possession. ${ }^{27}$

\footnotetext{
${ }^{23}$ Bossy (1965-1966:91-94). For the quotations, taken from notes by John Cecil on this correspondence, see Lambeth Palace Library, MS Fairhurst 2006, fols. 195 and 206 (cf. ABSI, Persons Letters $46 / 12 / 7,1311-18,1324$ and 1334). Grateful thanks to the archivist at Lambeth Palace Library, Mr Matti Watton, for permission to consult and quote from this manuscript.

${ }^{24}$ The identification by Martin and Finnis (2002-2003) has found general acceptance. For speculation that Sterrell/Rivers had dealings with Arbella Stuart, see Hume (1901:221, 275-76, 496-504). Hume worked extensively in the State Archives in Simancas as the editor of CSP Simancas.

${ }^{25}$ The Farnese claim depended on the same general line of descent, from John of Gaunt, as the Infanta. For Clement VIII's interest in marrying one of the Farnese brothers (sons of the military hero Alessandro Farnese, d. 1592) to Arabella Stuart, see the letter from Cardinal D'Ossat, French ambassador in Rome, to Henri IV, 26 Nov 1601 (Cooper 1886:1.131-45).

${ }^{26}$ James VI to R. Cecil, Feb or May 1602 (Akrigg 1984:191).

${ }^{27}$ Diary of John Manningham, 27/28 March and 7 April 1603 (Bruce 1896:153-54, 16o61); John Chamberlain to Dudley Carleton, 30 March 1603 (McClure 1939:1.190); G. C. Scaramelli, Venetian Secretary in England, to Doge and Senate, 12 April 1603 (CSP Venetian 10:2-3).
} 


\section{IV}

What was behind all these rumours we cannot tell, but it is clear at all events that Persons did not give up hopes of influencing the succession until the very end. It is also evident that he was entering the force-field of French politics and thus narrowing the gap between himself and his rivals among the Catholic exiles. Before we can draw any conclusions about the significance of these developments, we need to consider what was happening among the lay Catholics in England itself, the peers and the gentry. We have seen that there were some who were agitating for insurrection and foreign aid, but for the most part they were not prepared for any intervention. This is not to say that they were supine; indeed one of the most important developments in recent scholarship on the English Catholic community has been to demonstrate how many options they exercised, apart from recusancy, to express their dissatisfaction with, if not loathing and contempt for, the Protestant regime (Walsham 2000). It has often been pointed out that leading Catholic gentry, such as Sir Thomas Tresham and Sir George Shirley, and the Lords Mordaunt and Monteagle, were pro-active in securing James's accession immediately after the death of the queen (Kaushik 1996; Sena 2000; Questier 2006). But this was not a sign of welcome and acceptance: far from it; it was a purposeful attempt to place him under an obligation to honour his promises to them. If we read Tresham's own account of his ride into Northampton to have the king proclaimed at once, we are struck by the nervous excitement. He took great risks to ensure that his loyalty to James was noted, determined to be first in the queue. He broke in to the town, pushed his way through the crowds to the mayor's house, and had the postboy blow his horn. When the Mayor failed to come down to face five hundred hostile townsfolk, Tresham mounted the stairs to the mayoral chamber and confronted his peers. The only armed man in the company, Sir Robert Spencer, spoke for the rest and advised that they should wait twenty-four hours. Doubt was expressed whether James would uphold the Protestant religion, and this afforded delicious opportunity for Tresham to shame the rest by professing his allegiance irrespective of religion. ${ }^{28}$

\footnotetext{
${ }^{28}$ Tresham Papers, Rushton Hall, Northamptonshire (HMC Various Collections 3:1-154, esp. 117-23).
} 
If he had failed, Tresham could have been charged with high treason. He was a brave and reflective man who was renowned for the sacrifices he made for his faith. Some idea of what kind of England he wanted can be gleaned from the well-known Petition apologeticall (1604) which he and other Catholic loyalists presented to the king on his accession and subsequently had published at a secret Catholic press in London. On first glance this might seem to be a craven submission in the hopes of some small favour, some crumbs of toleration dropped from the monarch's table, for it includes an offer to stand surety for the good behaviour of the priests - not an arrangement likely to appeal to the Jesuits, who owed special obedience to His Holiness. We are reminded of the way the appellants were ready to trade in the Jesuits, whom in any case they hated, so that they themselves could be left in relative peace. But the lay Catholics of 1603 and 1604 addressed the king as gentlemen and knights to their liege. They asked for restoration of "their natiue freedome in this your Realme of England," moved to defend themselves by their responsibility for God's honour and their own and their children's good estate. They appealed to the king to increase his own honour, glory and triumph, as a father towards his children, by restoring so many of his subjects to freedom and prosperity. This is the language of free men, who rise above servile begging, to assert their ancient rights. They also asked for the liberty to exercise their allegiance to his majesty without the least shadow upon their integrity, already released as they now were from the constitutional and international obstacles that troubled them under Elizabeth, whom they had obeyed as their sovereign despite excommunication and illegitimacy.

Further signs of the lay Catholics' independence of spirit can be detected in their treatment of recusancy and the possible embarrassment of belonging to the same faith as the infamous "Doleman." They argued against church attendance on grounds that were more jurisdictional than theological: since the truth about religion had not been established by due ecclesiastical authority, it was unjust to compel them to worship against their consciences. They therefore called for the summoning of a conference to adjudicate on religious controversy, reminding the king how many of them had attended the debates in the Tower in the last days of Edmund Campion. As for Doleman, they dissociated themselves from him, but rather than indulge in overheated rhetoric against 
him, like the appellants or indeed Constable, they left him to make his own satisfaction to the king, as (no doubt) he had already done.

Here, then, is some common ground among the three voices we have heard addressing the succession question from a Catholic point of view: the recourse to a residual code of chivalry. Although Tresham and his friends differed sharply from Persons and the socalled Hispaniolated exiles on the question of foreign intervention, on which any alternative to James's succession necessarily depended, they honoured him. The most striking example of this unity of spirit is to be found in a two-volume manuscript of recusant materials in the Bodleian Library, which is known as the Jollet Miscellany. The pseudonymous scribe has organized large amounts of theological, devotional and historical matter under various headings, arranged chronologically and entered in ornamental panels. Tresham is treated as a hero of the faith, and so is Persons, repeatedly and conspicuously. There are accounts of Alabaster's conversion and even an entry recording William Gifford's acceptance of Persons as Allen's successor as leader of the Catholics in exile. ${ }^{29}$ This early seventeenth century collection provides an intriguing glimpse into the mentality of the educated Catholic layman, remembering with pride the heroes and martyrs of the recent past and keeping up to date with Roman apologetics. Such a man would be quietly confident of the outcome of any ecumenical conference on religious differences.

It is customary to stress the animosity between the Jesuits and the seculars, the Spanish and French factions among the exiles, the loyalists and the militants at home, the recusants and the church papists. These groupings have their value, and it is possible to line them up quite neatly, at least for the first three categories: proSpanish pro-Jesuit militants and pro-French anti-Jesuit loyalists, but we can see that men like Tresham do not fit these neat categories. The more we know about occasional conformity, that is, the resistance or protest strategies of those who were not full-blown recusants, the more we understand how tough the English Catholic community really was. This suggests to me that Persons was not as

\footnotetext{
${ }^{29}$ Two volumes of materials in defence of Roman Catholicism, arranged in 93 "books" by Thomas Jollet (pseud.), a convert with Northamptonshire connections, about 16051608, Bodleian Library, MS Eng. Th. b1-2: see especially Vol. 1: 235 (Alabaster), 250, 569 (Persons), 572, 822-36 (Tresham), Vol. 2: 31-32, 241-42 (Persons), 33 (Gifford).
} 
alienated from his co-religionists, not so easily treated as an extremist, as one may be tempted to assume, although Peter Guilday (1914:115) may well be right when he suggests that there were many Catholics who breathed a sigh of relief when he expired in the Easter season of 1610. And it prompts reflection on one final group of Catholics whose strategy over the succession we have not yet discussed: the peers.

Michael Questier (2006:1) has memorably encapsulated the standard judgement of the Catholic or crypto-Catholic peers as "vertebraically challenged;" an assessment we might be tempted to endorse when we read the account of the response of the Privy Council to James's questions about mitigation of the recusancy laws on 14 September 1604 (Loomie 1963b:55-56). Virtually everyone spoke in favour, but no one seems to have lifted a finger when the recusancy laws were in fact reinforced. Were they all merely yesmen? There might have been some hope of Buckhurst, who had assisted Persons when he left Balliol and travelled to the continent in 1574, and whose son was thinking of joining the Jesuits (Manning 1969:233-34; Edwards 1995:10-11; Pollen 1920:80-81). When the Anglo-Spanish peace conference convened in Boulogne in 1600 , for example, it was expected that Buckhurst would help to broker a new deal for the English Catholics, but the initiative fell through. ${ }^{30}$ Another crypto-Catholic, Northampton, became Cecil's go-between in the secret negotiations with James about the succession from 1601 onwards, a process that in effect guaranteed James's success (although we should be careful about regarding this as a common assumption at the time). ${ }^{31}$ The "Wizard Earl" of Northumberland, Henry Percy, was engaged in an important correspondence with James at the same time, posing as an important advisor on Catholic affairs. In the early spring of 1602 he wrote:

For the papists, it is treue there faction is strong, there encrese is dayly, and there diffidence in your maiestie is not desperat. Somme of the purer sort of them, who hath swaloued the doctrine of

\footnotetext{
${ }^{30}$ Hicks (1955:112-23) gives an account of Persons's dealings with Buckhurst at the time of the peace negotiations; see also Garnet's letter to Persons, 14 January 1600 (ABSI, Collectanea P 546).

${ }^{31}$ "Father Antony Rivers" noted the elevation of Lord Henry Howard to Earl of Northampton on 4 April, 1603 (Foley 1875-1883:1.58); on Northampton's correspondence with James, and his crypto-Catholicism, see Peck (1982:18-22, 54-57).
} 
putting doune princes for religion, may perhapps be whoter then there were reason, wishing the enfanta a better $\mathrm{sc}[\mathrm{h}]$ are in the kingdome then your selfe. But since your maiestie vnderstandeth better whow to leede this cause then I can giue instruction, I will dare to say no more, bot it weare pittie to losse so good a kingdome for the not tollerating a messe in a corner (if wppon that it resteth) so long as they sall not be too busy disturbers of the guuernement of the state, nor seeke to make vs contribitors to a peter prist. ${ }^{32}$ (Bruce 1861:56)

There is an appeal here to the king to be magnanimous, an appeal that is extended in another post-accession supplication, which suggests that the Catholics are a nation within a nation, thus making James not only the King of Scotland and England, but of yet another rich commonwealth - of English Catholics. All this suggests that the Catholic sympathisers among the peerage were taking risk-free action where possible to alleviate the plight of individual Catholics and trying to nudge policy in the direction of toleration. They were, in short, "politiques," and that is how Persons and his friends describe them in their letters.

The term politique denotes those Catholic noblemen in France who, sick of religious wars and impatient of the League, supported the accession of the Huguenot Henri of Navarre on the grounds that religion should not be the determining factor in state affairs. In making political decisions, political stability was more important than religious orthodoxy. This position is associated with the growth of absolutism and the doctrine of the divine right of kings but for many it was a purely pragmatic stance. It is more or less the position adopted by Constable in his response to Doleman. In the first book of The Conference about the Next Succession Persons developed at length a contractual theory of kingship, arguing that the monarch's first obligation was to promote the spiritual wellbeing of the realm. However, once the book came under fire from fellow Catholics, both before and after publication, he prepared a Latin translation for the Father General Acquaviva and the Pope, which cut almost all of this theory and concentrated on the genealogical evidence. Commentators such as Peter Holmes (1980) and Stefania Tutino (2009) have explained this alteration as a response to the changed conditions in France following Henri's conversion and to the

\footnotetext{
${ }^{32}$ James replied before 1 May 1602 (Akrigg 1984:188).
} 
dynamics of the papal court. And indeed it does appear that the gap was narrowing between those who would accept nothing less than a Catholic successor and those who would settle for peaceful coexistence.

You could never call Persons a politique. His heart was set on a government-sponsored programme of restoration, and he wrote a treatise, A Memorial for the Intended Reformation of England, for the attention of the Infanta in 1596 (Persons 1690). He would not swerve from his insistence on James's conversion as a precondition for endorsement, and when it came to conferences on religion he expected not a gentlemen's agreement to fudge the differences but the resounding triumph of Catholic truth. Yet he was not so much intransigent as unwilling to be duped. It seems clear from the developments from 1601 to 1603 , as the French settlement in church and state came to loom increasingly larger in all considerations of the English succession, that the groups represented by Persons, Constable and Tresham shared a commitment to keeping faith. From the monarch they looked for reverence for the ancient religion whether this was a contractual obligation guaranteed by Catholic hierarchy or a question of honour based on a chivalric code. From their opponents they expected due form and respect for the rules of polemic. Faction did not easily dissolve, and James took full advantage of the divisions, but it is possible to see, in the Catholic manoeuvrings in Elizabeth's last years, the potential for future realignments.

\section{References and abbreviations}

Akrigg, G. P. V. 1984. Letters of King James VI \& I. Berkeley and Los Angeles: University of California Press.

Bagley, J. J. 1985. The Earls of Derby, 1485-1985. London: Sidgwick \& Jackson.

Bell, Thomas 1603. The anatomie of popish tyrannie. London: I. Harrison for R. Bankworth.

Bossy, John 1961-1962. "A Propos of Henry Constable." Recusant History 6: 228-37.

- 1965-1966. "Henri IV, the Appellants and the Jesuits." Recusant History 8: 80-122.

Brown, Rawdon, George Bentinck, Horatio F. Brown and A. B. Hinds, eds. 1864-1947. Calendar of State Papers and Manuscripts, Relating to English 
Affairs, Existing in the Archives and Collections of Venice, and in Other Libraries of Northern Italy. 38 vols in 40. London: Longman, Green \& Co.

Bruce, John, ed. 1861. Correspondence of King James VI of Scotland with Sir Robert Cecil and Others in England, during the Reign of Queen Elizabeth. Camden Society 78. London: Camden Society.

ed. 1896. Diary of John Manningham, of the Middle Temple, and of Bradbourne, Kent, Barrister-at-Law, 1602-1603. Camden Society 99. London: J.B. Nichols \& Sons.

Collinson, Patrick 2014. "Bishop Richard Bancroft and the Succession." Eds. Susan Doran and Paulina Kewes. Doubtful and Dangerous: The Question of Succession in late Elizabethan England. Manchester: Manchester University Press: 92-111.

Constable, Henry 1589. Examen pacifique de la doctrine des Huguenots: Prouuant contre les Catholiques rigoureux de nostre temps $\mathcal{E}$ particulierement contre les obiections de la response faicte a l'Apologie Ctholique [sic], que nous qui sommes membres de l'Eglise Catholique Apostolique \& Romaine ne deurions pas condemner les Huguenots pour heretiques iusques a ce qu'on ait faict nouuelle preuue. Paris, vere London: J. Wolfe.

- 1600. A discoverye of a counterfecte conference helde at a counterfecte place, by counterfecte travellers, for thadvancement of a conterfecte tytle, and invented, printed, and published by one (PERSON) that dare not avowe his name. Cologne, vere Paris: Charles Paget.

1623. The Catholic Moderator: or A moderate examination of the doctrine of the Protestants. Prouing against the too rigid Catholikes of these times, and against the arguments especially, of that booke called. The answer to the Catholike apologie, that we, who are members of the Catholike, apostolike, and Roman Church, ought not to condemne the Protestants for heretikes, ontill further proofe be made. Trans. W. W. London: Nathaniel Butter for Eliot's Court Press.

Cooper, Elizabeth 1886. The Life and Letters of Lady Arabella Stuart. 2 vols. London: Hurst \& Blackett.

$C S P D>$ see Lemon and Green (1856-1872).

CSP Simancas $>$ see Hume (1892-1899).

CSP Venetian > see Brown, Bentinck, Brown and Hinds (1864-1947).

Daussy, Hugues 2002. Les Huguenots et le roi: Le combat politique de Philippe Duplessis-Mornay (1572-1600). Geneva: Droz.

Doleman, R. 1595. A Conference about the Next Succession to the Crowne of Ingland > see Persons, R. (1595). 
Doran, Susan and Paulina Kewes, eds. 2014. Doubtful and Dangerous: The Question of Succession in late Elizabethan England. Manchester: Manchester University Press.

Edwards, Francis 1995. Robert Persons: The Biography of an Elizabethan Jesuit, 1546-1610. St Louis: Institute of Jesuit Sources.

Foley, Henry 1875-1883. Records of the English Province of the Society of Jesus. 7 vols in 8. London: Burns \& Oates.

Guilday, Peter 1914. The English Catholic Refugees on the Continent 1558-1795. Vol. 1. The English Colleges and Convents in the Catholic Low Countries, 1558-1795. London: Longmans, Green, \& Co..

Hammer, Paul E.J. 1999. The Polarisation of Elizabethan Politics: The Political Career of Robert Devereus, 2nd Earl of Essex, 1585-1597. Cambridge: Cambridge University Press.

Hicks, L. 1955. "Sir Robert Cecil, Father Persons and the Succession." Archioum Historicum Societatis Iesu 24: 95-139.

- 1957-1958. "Father Robert Persons, S.J. and the Book of Succession." Recusant History 4: 104-37.

HMC Hatfield House > see Roberts, Salisbury, Guiseppi and Owen (18831976).

HMC L'Isle > see Lethbridge, Shaw and Owen (1925-1966).

HMC Various Collections > see Lomas (1904).

Holmes, Peter 1980. "The Authorship and Early Reception of A Conference about the Next Succession to the Crown of England." Historical Journal 23: $415-29$.

Houliston, Victor 2000. "The Hare and the Drum: Robert Persons's Writings on the English Succession, 1593-1596." Renaissance Studies 14: 235-50.

2008. "Shaming and Containing: Robert Persons Sets the Standards for Ecclesiastical Tournaments." Southern African Journal of Medieval and Renaissance Studies 18: 89-120.

Hume, Martin A. S. 1892-1899. Calendar of Letters and Papers relating to English affairs preserved principally in the archives of Simancas. 4 vols. London: Eyre and Spottiswood for HM Stationery Office.

1901. Treason and Plot: Struggles for Catholic Supremacy in the Last Years of Queen Elizabeth. London: James Nisbet.

Jenkins, Gladys 1948. "The Archpriest Controversy and the Printers, 16011603." The Library, 5th ser. 1: 180-86.

Kaushik, Sandeep 1996. "Resistance, Loyalty and Recusant Politics: Sir Thomas Tresham and the Elizabethan State." Midland History 21: 37-72. 
Knox, T. F. 1882. Letters and Memorials of Cardinal Allen (1532-1594). London: David Nutt.

Law, T. G. 1904 (1893). "The Spanish Blanks and the Catholic Earls, 15921594." Ed. P. Hume Brown. Collected Essays and Reviews of Thomas Graves Law, LL.D. Edinburgh: T. \& A. Constable: 244-72.

Lecey, John 1604. A petition apologeticall $>$ see Tresham, Thomas (1604).

Lee, Maurice, Jr. 1970. James I and Henri IV: An Essay in English Foreign Policy, 1603-1610. Urbana: University of Illinois Press.

Lemon, R. and M. A. E. Green, eds. 1856-1872. Calendar of State Papers, Domestic Series, of the Reigns of Edward VI, Mary, Elizabeth [and James I] 1574-1625. 12 vols. London: HM Stationery Office.

Lennon, Colm 1980. Richard Stanihurst: The Dubliner, 1547-1618. Dublin: Irish Academic Press.

Lethbridge, Charles, William Arthur Shaw and Geraint Dyfnallt Owen, eds. 1925-1966. Report on the Manuscripts of Lord de L'Isle $\mathcal{E}$ Dudley: preserved at Penshurst Place. Royal Commission on Historical Manuscripts. 6 vols. London: HM Stationery Office.

Lomas, S. C., ed. 1904. The Manuscripts of T. B. Clarke-Thornhill, Esq., Sir T. Barrett-Lennard, Bart., Pelham R. Papillon, Esq., and W. Cleverly Alexander, Esq. Report on Manuscripts in Various Collections 3. Royal Commission on Historical Manuscripts. London: HM Stationery Office, 1904.

Loomie, Albert J. 1963a. The Spanish Elizabethans: The English Exiles at the Court of Philip II. New York: Fordham University Press.

- 1963b. "Toleration and Diplomacy: The Religious Issue in AngloSpanish Relations, 1603-1605." Transactions of the American Philosophical Society, n.s. 53.6: 1-52.

- 1963-1964. "A Catholic Petition to the Earl of Essex." Recusant History 7: $33-42$.

- 1965. "Philip III and the Stuart succession in England, 1600-1603." Revue belge de Philologie et d'Histoire 43: 492-514.

-1973. Spain and the Jacobean Catholics. Vol I: 1603-1612. Publications of the Catholic Record Society 64. London: Catholic Record Society.

Lovell, Mary S. 2005. Bess of Hardwick: First Lady of Chatsworth. London: Little, Brown.

Manning, Roger B. 1969. Religion and Society in Elizabethan Sussex: A study of the enforcement of the religious settlement, 1558-1603. Leicester: Leicester University Press.

Martin, A. Lynn 1973. Henry III and the Jesuit Politicians. Geneva: Droz. 
Martin, Patrick and John Finnis 2002-2003. "The Identity of 'Antony Rivers'." Recusant History 26: 39-74.

McCann, Justin 1952. Ampleforth and its Origins: Essays on a Living Tradition. London: Burns Oates and Washbourne.

McClure, N. E., ed. 1939. Letters of John Chamberlain. 2 vols. Philadelphia: American Philosophical Society.

McCoog, Thomas M. 2004. "Harmony Disrupted: Robert Parsons, S.J., William Crichton, S.J. and the Question of Queen Elizabeth's Successor, 1581-1603." Archivum Historicum Societatis Iesu 73: 149-220.

Medina, Francisco de Borja 1996. "Intrigues of a Scottish Jesuit at the Spanish Court: Unpublished Letters of William Crichton to Claudio Acquaviva (Madrid 1590-1592)." Ed. Thomas M. McCoog, The Reckoned Expense: Edmund Campion and the Early English Jesuits. Woodbridge, Suffolk: The Boydell Press: 215-45.

Mornay, Philippe de 1598. De l'Institution, usage, et doctrine du Sainct Sacrement de l'Eucharistie, en l'Église ancienne. Ensemble; Comment, quand, $\mathcal{E}$ par quels degrez la Messe s'est introduite en sa place. 2nd edition. La Rochelle.

160oa. Fowre Bookes, of the Institution, Use and Doctrine of the Holy Sacrament of the Eucharist in the old Church. As likewise how [...] the Masse is brought in, in place thereof. Trans. R. S. London: J. Windet for I. B., T. M., and W. P.

16oob. Discours véritable de la conférence tenue à Fontainebleau le quatriesme de may 1600, entre le sieur du Plessis at l'Évesque d'Évreux. Paris.

1600c. A Discourse of the Conference holden before the French King at Fontain-bleau, betwene the L. Bishop of Eureux, and Munsieur Plessis L. of Mornay, the 4 of May 1600. Concerning certaine pretended corruptions of Authours, cyted by the sayd Munsier du Plessis in his booke against the Masse. London: E.A. for Mathew Selman and William Ferbrand.

Patterson, W. B. 1997. King James VI and I and the Reunion of Christendom. Cambridge: Cambridge University Press.

Peck, Francis 1779. Desiderata Curiosa: Or, A Collection of Divers Scarce and Curious Pieces Relating Chiefly to Matters of English History. Revised edition. 2 vols. London: Thomas Evans.

Peck, L. L. 1982. Northampton: Patronage and Policy at the Court of James I. London: George Allen and Unwin.

Persons, Robert 1595. (R. Doleman, pseud.) A Conference about the Next Succession to the Crowne of Ingland. Antwerp: Arnout Conincx.

1604. The Third Part of a Treatise, Intituled: of three Conversions of England: conteyning. An Examen of the Calendar or Catalogue of Protestant 
Saints, Martyrs and Confessors, divised by John Fox [...] The first six monethes. Wherunto in the end is annexed a defence of a certaine Triall, made before the King of France upon the yeare 160o. betweene Monsieur Peron Bishop of Evreux, and Monsieur Plessis Mornay Governour of Saumur, about sundry points of Religion. A Treatise of Three Conversions 2. St Omer: François Bellet.

169o. The Jesuit's Memorial, for the Intended Reformation of England Under their First Popish Prince. Ed. Edward Gee. London: Richard Chiswel.

Pollen, J. H. 1903. "The Accession of King James I." The Month 101: 572-85.

1920. The English Catholics in the Reign of Queen Elizabeth: A Study of their Politics, Civil Life and Government. 1558-1580: From the Fall of the Old Church to the Advent of the Counter-Reformation. London: Longmans, Green and Co.

ed. 1906. "Memoirs of Father Robert Persons." CRS Miscellanea II. Publications of the Catholic Record Society 2. London: Catholic Record Society: 12-218.

Questier, Michael C. 2005. "Elizabeth and the Catholics." Ed. Ethan Shagan. Catholics and the "Protestant nation." Manchester: Manchester University Press: 69-94.

2006. Catholicism and Community in Early Modern England: Politics, Aristocratic Patronage, and Religion, c. 1550-1640. Cambridge: Cambridge UP.

Roberts, Richard Arthur, Edward Salisbury, Montague Guiseppi and Geraint Dyfnallt Owen, eds. 1883-1976. Calendar of the Manuscripts of the Most Hon. the Marquis of Salisbury, K.G., Ec. [...] preserved at Hatfield House, Hertfordshire. Royal Commission on Historical Manuscripts. 24 vols. London: HM Stationery Office.

Rogers, David 1959-1960. "The Catholic Moderator: A French Reply to Bellarmine and its English Author, Henry Constable." Recusant History 5: 224-35.

Sena, Margaret 2000. "William Blundell and the networks of Catholic dissent in post-Reformation England." Eds. Alexandra Shepard and Phil Withington. Communities in Early Modern England: Networks, Place, Rhetoric. Manchester and New York: Manchester University Press: 54-75.

Stafford, H. G. 1940. James VI of Scotland and the Throne of England. American Historical Association. New York and London: Appleton-Century.

Stroud, Theodore A. 1951. "Father Thomas Wright: A Test Case for Toleration." Biographical Studies 1: 189-219.

Sutton, Dana F. 1997. Introduction. Unpublished Works by William Alabaster. Salzburg: University of Salzburg. 
Tresham, Thomas 1604. (John Lecey, pseud.) A petition apologeticall, presented to the Kinges most excellent Maiesty, by the lay Catholikes of England, in Iuly last. Douai: Iohn Mogar, at the signe of the Compas, vere English secret press, connected with William Wrench.

Tutino, Stefania 2009. “The Political Thought of Robert Persons's Conference in Continental Context." The Historical Journal 52: 43-62.

Walsham, Alexandra 200o. "Yielding to the Extremity of the Time': Conformity, Orthodoxy and the Post-Reformation Catholic Community." Eds. Peter Lake and Michael Questier. Conformity and Orthodoxy in the English Church, c. 1560-1660. Woodbridge, Suffolk: The Boydell Press: 211-36.

Watson, William 1602. A Decacordon of Ten Quodlibeticall Questions concerning Religion and State. London: Richard Field.

Wickes, George 1953-1954. "Henry Constable, Poet and Courtier (15621613)." Biographical Studies 2: 272-300.

How to cite this article:

Houliston, Victor. "Filling in the Blanks: Catholic Hopes for the English

Succession." SEDERI 25 (2015): 77-104.

Author's contact: Victor.Houliston@wits.ac.z

Postal address: School of Literature, Language and Media - University of the

Witwatersrand - 1 Jan Smuts Avenue - Braamfontein 2000 -Johannesburg, South Africa

Submission: 1/13/2015

Acceptance: 2/18/2015 